\title{
Питання психології
}

УДК: 159.923.2:159.9.072

DOI: $10.33099 / 2617-6858-20-58-5-113-122$

Кучерява Т. О. здобувач науково-дослідноїлабораторії

екстремальної та кризової психології науково-дослідного центру Національного університету циивільного захисту Украӥни https://orcid.org/0000-0001-8033-9159

\section{МОДЕЛЬ ПСИХОЛОГІЧНОЇ НАДІЙНОСТІ ТАНКОВОГО ЕКІПАЖУ}

Стаття присвячена висвітленню проблеми психологічної надійності групи під час виконання колективної діяльності. Проаналізовано особливості дослідження надійності особистості в індивідуальній діяльності фахівия з позиції інженерної психологї, індивідуально-психологічні характеристики професійної надійності суб'єкта діяльності та надійності професійної діяльності фахівиів екстремального профілю. Визначено специфіку особистісної надійності професіонала у групі та надійності групи. Розроблено модель психологічної надійності танкового екіпажу, в якій відображено змістові компоненти психологічної надійності танкового екіпажу як изілісної групи у складі особистісної надійності та групової надійності, поєднаних суб'єктністю колективної діяльності.

Ключові слова: танковий екіпаж; психологічна надійність; групова діяльність; особистісна надійність; групова надійність; модель психологічної надійності.

Постановка проблеми. Проблематиці надійності в межах психологічної науки стали приділяти увагу достатньо давно, 3 появою проблеми забезпечення високих показників результативності діяльності, недопущення помилок суб'єктом діяльності, збереження стабільних показників під час виконання професійних завдань у складних умовах тощо. Вперше надійності почали приділяти увагу саме в дослідженнях інженерної психології та психології праці. Інженерна психологія порушила питання про надійність професійної діяльності, під якою прийнято було розуміти безпомилкове виконання фахівцем покладених на нього професійних обов'язків протягом певного необхідного часу і за певних умовах діяльності. 3 появою складних технічних засобів і автоматизованих систем управління «вартість» людських помилок стала відчуватися особливо гостро. 3 часом більш актуальними ставали питання наслідків помилок, які можуть буги допущені фахівцем в своій професійній діяльності, значні економічні, соціальнопсихологічні і навіть екологічні наслідки але найбільш страшними з них є загибель людей.

Значний внесок в розроблення питання надійності фахівців екстремального профілю діяльності здійснили дослідження В.О. Бодрова, К.М. Гуревича, М.С. Корольчука, Г.В. Ложкіна, Б.Ф. Ломова, М.В. Макаренка, В.Л. Марищука, В.Д. Небиліцина, Г.В. Суходольського та багатьох інших. Але, незважаючи на це, сьогодні назвати достатньо розробленим питання психологічної надійності фахівців військово-професійної діяльності у тому числі в групової не можна. Адже стрімкий прогрес у технічній галузі майже унеможливлює вирішення цього питання через постійний розвиток новітніх технічних засобів, автоматизацію діяльності, через ускладнення технічного устаткування майже будь-якого виду діяльності людини, через невичерпну проблему допущення фахівцем помилок у своїй професійній діяльності.

Аналіз останніх досліджень і публікацій. Суттєвий внесок у розроблення проблематки надійності роботи операторів здійснили В.О.Бодров, А.І. Губінський, Г.М. Зараковський, Є.О. Клімов, М.А. Котик, Б.Ф. Ломов, Н.Ф. Лукьянова, В.Л. Маріщук, Г.С. Нікіфоров, К.К. Платонов, В.О. Пономаренко, Г.В. Суходольский і багато інших. У цих роботах актуальною стала теза про те, що однією 3 найважливіших характеристик складної технічної системи $\mathrm{\epsilon}$ надійність: надійність технічного обладнання та надійність фахівця, який на ньому працює.

Історично, культурно i психологічно поняття «надійність» фіксувало одну 3 найважливіших меж розуміння світу, поведінки i діяльності в ньому людини. В.М.Круком відмічалось, що дане поняття спочатку складалося як особистісно-функціональнодіяльнісна характеристика людини. I тільки 


\section{Питання психології}

потім поняття «надійність» проникло спочатку в технічні та природничі науки, а ще пізніше - в психологію, отримавши там оформлення у вигляді «проблеми надійності» [9].

Особливого розвитку питання надійності набуло в межах напряму, пов'язаного 3 вивченням професійної діяльності особистості. Надзвичайно активно це питання вивчалось під час взаємодії людини 3 технікою в різноманітних системах: на підприємствах атомної енергетики, в авіації, космонавтиці, на автомобільному i залізничному видах транспорту. С роботи, в яких вивчається надійність моряків, військових фахівців і ін. [1].

Міцний зв'язок проблеми надійності 3 технічною галуззю, обумовив актуалізацію іiі досліджень в межах інженерної психології. Надійність людини-оператора визначається в даному аспекті, як те що визначається запасом міцності. Г.В. Суходольський визначає надійність як протилежну категорію ненадійності - властивості допускатись помилок під час виконання професійних завдань [1]. Існує думка, що надійність діяльності людини-оператора - це тривалість безвідмовної роботи суб'єкту діяльності протягом певного часу. В окремих дослідженнях йдеться про те, що поняття «надійність діяльності» визначаєтся відсутністю помилкових дій або вірогідністю їх появи (Г.С. Нікіфоров, В. Хаккер), працездатністю людини та іii здатністю до збереження оптимальних робочих параметрів, які необхідні для виконання діяльності в екстремальних умовах (В.Ф. Венда, А.І. Губінський, Є.О. Мілерян), як здатність зберігати необхідні для виконання діяльності якості в надскладних i мінливих умовах (B.О. Пономаренко, Н.Д.Завалова), психофізіологічну «ціну» діяльності як ступінь напруження регуляторних механізмів психіки та величину затрат функціональних резервів організму (О.Ф. Бобров, В.Ю. Щебланов) [10].

Стосовно досліджень професійної надійності, що стосувались вивчення надійності конкретного фахівця, або суб'єкта конкретного виду діяльності, вони отримали статус наукової проблеми в межах авіаційної, космічної психології, інших галузей, які пов'язані 3 технічними рішеннями окремого фахівця чи групи фахівців.
Дослідженням надійності космонавтів присвячено роботи Б.Ф. Ломова. Він дотримується позиції, що професійна надійність космонавта може розумітись як своєрідний фактор ризику безпечності космічного польоту. Психологічним аспектом цього питання він вважав забезпечення ефективної професійної діяльності. Таку позицію вчений пояснював існуванням низки таких детермінант: «професійна шкідливість», яка виражається в екстремальності діяльності; значне професійнопсихологічне навантаження; висока імовірність виникнення позаштатних ситуацій тощо. При цьому ефективну групову взаємодію в процесі діяльності та попередження можливого розвитку напруження між іiі членами можна назвати умовами для забезпечення професійної надійності. Ці умови можуть бути реалізовані через досягнення психологічної сумісності членів групи, з урахуванням їх професійних та психологічних особливостей [1].

Надійність була предметом дослідження проблеми професійної надійності льотчиків в зв'язку 3 нападами в процесі безперервної діяльності (Ф.Д. Горбов); в рамках проблеми безаварійності польотів у військово-повітряних силах (П.А. Корчемний); деякі психологічні аспекти надійності в діяльності офіцерів військово-морського флоту (М.С. Корольчук, П.П. Криворучко; Б.Я. Шведін); діяльності фахівців водолазних формувань аварійнорятувальних підрозділів МНС (О.В.Тімченко, Д.В. Лєбєдєв, С.Ю. Лєбєдєва, О.О.Назаров, Н.В. Оніщенко); професійної та функціональної надійності фахівців снайперських груп спеціальних підрозділів МВС (О.В. Тімченко, С.Ю. Лєбєдєва) тощо.

Але особливої уваги заслуговуе дослідження проблеми групової надійності або надійності особистості в груповій діяльності. Оскільки нами досліджується проблема надійності членів танкового екіпажу, особливо актуальними для нас $€$ питання вивчення надійності на груповому рівні. Враховуючи те, що група має більш складний, у співвідношенні з індивідом, соціально-психологічний зміст, то спроби вивчення цього питання на груповому рівні можна вважати достатньо специфічними. Ми розуміємо, що як на особистісному, так і на груповому рівнях зміст надійності може визначатись особливостями цільового, 


\section{Питання психології}

ціннісного, мотиваційного, діяльнісного, міжособистісного, поведінкового та іншими компонентів.

Метою статті є визначення психологічних особливостей надійності особистості в груповій діяльності та розроблення моделі психологічної надійності танкового екіпажу.

Виклад основного матеріалу. В межах дослідження надійності груп слушною $€$ позиція М.I. Сєтрова, який запропонував деякі принципи іï оцінки. Дотримуючись системнофункціонального підходу в дослідженні надійності груп, яка сама по собі, на думку автора, представляє певну «підсистему» динамічної психологічної структури будь-якої групи, можливо виділення наступних критеріїв оцінки іiі надійності: 1) сумісність, яка відображатиме необхідність наявності щодо однорідних елементів i самого факту їх взаємодії, що $\epsilon$ найважливішим умовою існування системи; 2) ступінь актуалізації функцій для збереження системи в складних умовах; 3) рівень нейтралізації дисфункцій, що демонструє спосіб підтримки «рівноваги» системи; 4) стан зосередження функцій, що відображає необхідність їх узгодження з метою досягнення необхідного результату [13].

Схожу позицію демонструє i O.C. Чернишов. Аналізуючи організованість груп, він виділяе низку показників, що характеризують в той же час їх надійність [12]. До таких можна віднести: психологічний настрій на діяльність, сенсомоторну узгодженість реакцій, єдність думок членів групи, спільність міжособистісних відносин, що характеризує такий стан статусної структури, при якому відсутні «крайні ланки». Це дозволяе, на теоретичному рівні, до організаційних властивостей надійності груп віднести: спрямованість, самоврядування, наявність лідерства, єдність дій, стресостійкість та міжгрупову єдність.

Соціально-психологічним аспектам зв'язку між надійністю і організованістю присвячено дослідження і С.В.Саричева [12]. У роботі надійність групи ним розуміється як часовий параметр, що характеризує динаміку спільної діяльності і поведінки щодо ситуації і часу. Даний параметр, 3 точки зору психології, дозволяс охарактеризувати певний оптимальний рівень функціонування даної групи на певному відрізку часу. Надійність групи в напружених і екстремальних ситуаціях спільної діяльності, за оцінкою С.В. Саричева, детермінована організованістю групи, а організованість виступає опосередкованим фактором надійності [12].

Окремої уваги заслуговує питання вивчення особливостей надійності фахівців екстремальних видів діяльності. Ціла низка професій припускає виконання людиною своїх професійних завдань в несприятливих для цього умовах. До таких негативних факторів можна віднести: фізико-хімічні фактори середовища (мікрокліматичні, радіаційні, механічні, фізичні, зміни газового складу повітря i iн.), інформаційно-семантичні (недолік, надлишок, хибність, розшарування інформації, висока індивідуальна або суспільна значущість праці, сенсорна депривація і ін.), біологічні (вітальна загроза) та інші фактори [8]. Під впливом цих факторів значно знижується надійність діяльності фахівців.

Дослідниками описується досить широкий діапазон форм прояву напружених ситуацій у спільній діяльності фахівців: від різкого зниження організованості поведінки і дезорганізації діяльності до підвищення іiі ефективності. Порушуються, за оцінкою авторів, перш за все, складні дії за відносної стійкості. При цьому відбувається «прискорення» i підвищення «Гнучкості» психічних процесів, відбувається «активізація» психіки [8]. Це свідчить про неоднозначність впливу напружених ситуацій на різні групи фахівців.

Проблема надійності професійної діяльності фахівців екстремального профілю тісно пов'язана з психологічною сумісністю та ефективністю групової діяльності. У зв'язку з цим значний науково-практичний інтерес представляє питання вивчення надійності фахівців, які виконують сумісну діяльність в складних екстремальних умовах.

Проведений аналіз досліджень 3 проблеми особистісної надійності у групі та надійності групи показав ряд їх особливостей. Зокрема науковці (В.О. Бодров, М.С.Корольчук, Г.В. Ложкін, М.В. Макаренко, В.I. Осьодло) наголошують на таких важливих індикаторах надійності професійної діяльності як працездатність та функціональні можливості 


\section{Питання психології}

спеціаліста, що досліджуються за критеріями продуктивності в діяльності, якості виконання, витривалості та відновлюваності. Вони визначали властивості нервової системи та функціональних можливостей аналізаторів основними детермінантами ефективності й надійності діяльності фахівців операторського профілю.

Серед таких важливих психофізіологічних властивостей, що забезпечують успішність i надійність, були вказані: сила нервової системи, довгострокова витривалість до напруженої діяльності, стійкість уваги, стійкість до численних перешкод і подразників зовнішнього середовища. Вчені зазначають, що їх дослідження доцільно проводити за допомогою чотирьох груп методик для визначення: 1) психофізіологічних якостей; 2) суб'єктивного стану; 3) прямих показників (характеризують кількість та якість праці); 4) побічних показників (характеризують функціональну динаміку фізичної та розумової праці) [1].

С.Ю. Лєбєдєва, О.В. Тімченко визначають професійну надійність як цілісну характеристику особистості працівника, складовими якої $є$ стійкість та стабільність функціонування основних психічних механізмів відносно професійної діяльності [10].

P.А. Шпак у дослідженні надійності професійної діяльності військових радіотелеграфістів серед основних діагностичних показників при підборі психодіагностичних методик визначає: оцінювання суб'єктивного стану (самопочугтя, активності, настрою); фізичні функціональні можливості організму (функціональних резервів серцево-судинної та дихальної систем), рівень витривалості та відновлюваності; силу нервової системи; працездатність (продуктивність, швидкість, точність (безпомилковість), витривалість); продуктивність психічних пізнавальних процесів (уваги, сприймання, слухової довготривалої й оперативної пам'яті); рівень вольової саморегуляції (наполегливість та самовладання); професійну мотивацію (мотиви власної праці, соціальної значущості діяльності, самоствердження, професійної майстерності); індивідуально-психологічні особливості (інтелектуальні, емоційно-вольові особливості, комунікативні властивості та особливості міжособистісних відносин) [14].

В дослідженні надійності групи I.О. Котик, С.В. Саричева [7, с. 297-298] в оптимальних, напружених та екстремальних умовах спільної діяльності описують за показниками 1) результативності, яка вимірюється за допомогою емпіричних референтів: часу $\mathrm{i}$ якості виконання завдання, кількості відмов (абсолютних і тимчасових), безвідмовності (питомої ваги завдань, виконаних без відмови), продуктивності спільної діяльності, рангу групи (за оцінкою експертів); 2) взаємодії членів групи, яку визначають емпіричними референтами: ієрархізації та варіативності взаємодії, структури взаємодії в групі, самостійності та ініціативності членів групи у взаємодії, залученням членів групи до взаємодії в ході спільної діяльності [12, с. 174]; 3) узгодженості дій, яка виміряна емпіричними референтами: наявності у групи єдиного плану спільної діяльності, ступеня деталізації плану спільної діяльності, розподілу і ступеня узгодженості функцій, чіткості виконання розробленого плану та відповідність йому дій членів групи [12, с. 176].

А.П. Дебренюк у своєму дослідженні обгрунтовує розгалужену систему критеріїв та показників характерологічних ознак успішності спільної діяльності військових операторів РЛС на бойовому чергуванні $[4$, с. 8$]$. При цьому 1$)$ критерій - суспільно-корисної усвідомленої діяльності відображають показники: усвідомлення мети i завдань бойового чергування, ставлення до службових обов'язків на бойовому чергуванні, суспільної активності; 2) критерій - бойової готовності відображають показники: своєчасного виконання завдань бойового чергування, точності виконання завдань бойового чергування; 3) критерій професійної (операторської) готовності відображають показники: ступеня повноти засвоєння операторських знань, навичок і вмінь, ступеня усвідомленості засвоєних операторських знань, ступеня реалізації засвоєних операторських знань, навичок i вмінь; 4) критерій - психологічної готовності відображають показники: рівня сформованості ціннісно-мотиваційного компонента, рівня сформованості орієнтовно-мобілізаційного компонента, рівня сформованості емоційно- 


\section{Питання психології}

вольового компонента; рівня сформованості пізнавально-оцінювального компонента; 4) критерій - загальної оцінки за зміну відображають показник оцінки виконання завдань за призначенням.

\section{В.В. Корнещук}

запропоновано математичну модель професійної надійності спеціалістів соціономічної сфери, в основу дослідження якої покладено вивчення пізнавальних психічних процесів, типологічних особливостей особистості, мотивації, психічних станів, міжособистісних відносин [5, с. 19]. Вчена визначає фактори, що можуть впливати (позитивно чи негативно) на професійну надійність фахівців, серед яких зокрема: складність професійного завдання, відповідальність, непередбаченість розвитку ситуації та іiї контролю, несприятливі психічні стани та фізіологічні особливості, нераціональний режим праці й відпочинку, недостатній розвиток професійно важливих якостей, недостатні професійні знання, вміння i навички, відсутність досвіду, суперечливість (надлишковість, недостатність, раптовість) інформації, неуспіх діяльності, низький розвиток моральних якостей, неадекватна оцінка діяльності й оплата праці, надмірне службове навантаження, несприятливий психологічний клімат колективу, загроза життю та здоров'ю [5, с. 17-18]. Серед критеріїв професійної надійності спеціалістів вчена виділяє прогнозованість - непрогнозованість результатів діяльності в типових і нетипових ситуаціях; усталеність - неусталеність діяльності під час виконання професійних функцій; гнучкість - ригідність поведінки в процесі діяльності [5, с. 23].

В.В. Горбунова [2] аналізуючи цінніснорольові параметри командотворення у структурі імпліцитних теорій командної взаємодії емпірично обгрунтовує іiі цінніснорольову картографію. За результатами дослідження в авторській моделі цінніснорольової інтеракції у командах вченою обрано психосемантичну схему організації дослідження, що дало змогу визначити особливості вибору особистістю стратегій взаємодії та побудови взаємин із колегами у команді. Структурно організацію імпліцитних теорій командної інтеракції за рівнем іï ціннісної складності визначає сукупність параметрів

диференційованості, артикульованості та ієрархізованості. Аналіз інтерпросторовості командних взаємин дав змогу визначити сфери ціннісної кон'юнкції та диз'юнкції, спільне та відмінне у ціннісному сприйманні та інтерпретації командних ролей, співвіднести їх з поведінкою членів команди та визначити при цьому ціннісно-конгруентних осіб. Важливою умовою ефективної взаємодії у командах автор визначає ціннісно-рольову узгодженість, як кон'юнкцію членів команди у сприйманні та інтерпретації міжособистісної взаємодії. Результати цього дослідження свідчить про важливість співставлення параметрів сприймання та оцінки цінніснорольової взаємодії суб'єктів взаємодії в малій групі.

Сугтєвими в рамках нашого дослідження $\epsilon$ положення П.П.Горностая щодо розвитку групової ідентичності в малих групах, до яких ми відносимо танковий екіпаж. Зокрема вчений наголошує на тому, що групові психологічні феномени варто розглядати як деяке групове психологічне поле, що угворюється завдяки механізмам групової ідентифікації. Групове психологічне поле вчений визначає як обов'язкову умову життедіяльності i життєздатності групи та показник розвиненості відносин усередині неї у більш широкому контексті функціонування групової ідентичності. На першому рівні його феноменології в основі інтеграційних процесів в малих групах лежить групова ідентифікація; на другому рівні воно включає обмін інформацією (свідомою і несвідомою) всередині та зовні; третій рівень включає різноманітні продукти групової психіки (групові психологічні утворення, феномени) та їхнього функціонування (стереотипи, міфи, історії i таємниці, захисні механізми) [3].

Цінним також є положення про те, що процеси ідентифікації обумовлюють взаємодію особистісної та групової ідентичності, в результаті якої і виникає ідентичність групи як феномен групового психологічного поля, завдяки якому група набуває статусу групового суб'єкта. Важливим у даному контексті $\epsilon$ розвиток групової ідентичності танкового екіпажу до високого рівня набуття синергетичності, оскільки він передбачає не тільки ціннісну значущість групи для кожного 


\section{Питання психології}

члена, а й здатність відчувати один одного без прямої комунікації, високий рівень згуртованості, єдності, тобто так звану «групову психіку». На думку П.П. Горностая, така нова якість групової ідентичності дозволяє проявлятися групі як окремому суб'єкту, зберігати власну самобутність, автономію, цілісність, тобто відстоювати свою ідентичність [3].

Феномен суб'єктності групи за даними I.О. Котик, С.В. Саричева [6, с. 254-255] сприймається неоднозначно, втім саме суб'єктність відображає зміст спрямованості й рівень активності малої групи, оскільки саме в полі суб'єктності відображаються іï внутрішні соціально-психологічні характеристики (регулятивні функції групових норм, цінностей і санкцій, ефект фасилітації, соціабельність), що впливають на самопочуття, поведінку й продуктивність. А за даними В.І. Осьодла суб'єктність військового професіонала розглядається як інтегральна психічна якість, що включає прояви вищих якостей людини організатора власного життя й відображає усвідомлення своєї здатності здійснювати значущі перетворення на власному життєвому шляху, в об'єкті діяльності, інших людях і самому собі. Набуття суб'єктності пов'язане 3 досягненням професійної ідентичності через формування позитивного й адекватного образу «Я-професіонал» та переживання самоцінності, переосмислення власної професійної ролі, накопичення досвіду суб'єктної активності, актуалізацію рефлексивного й ціннісносмислового компонентів суб'єктного досвіду [11]. Суб'єктність групи таким чином буде грунтуватися на груповій ідентичності, позитивному взаємному ставленні в досвіді професійних взаємовідносин визначаючи тенденцію i здатність до ініціації та регулювання групової професійної активності відповідно до групових критеріїв ефективності і доцільності в ситуаціях, що передбачають певну свободу вибору й відповідальність за нього.

Дослідження В.М. Крука [9] показують, що під критерієм стійкості результатів спільної або сумісної діяльності в умовах, що змінюються в змістовному плані, слід розуміти незмінну результативність спільної діяльності, яку можна виміряти за наступними показниками: оцінки за виконання завдань, кількість помилок при виконанні завдань, час їх виконання. Прояв даного критерію надійності сумісної діяльності відповідає характеристикам спільної діяльності, які укладаються в поняття результативності. Тому його застосування для оцінки надійності груповий діяльності видається цілком допустимим і доречним.

На основі досліджень С.В.Саричева i А.С. Чернишева [12] такий критерій надійності сумісної діяльності, як узгодженість дій членів екіпажу, може оцінюватися за наступними показниками: сумісність членів екіпажу під час виконання спільної діяльності, взаємозумовленість дій при виконанні завдань, спосіб вирішення при цьому розбіжностей i рівень конфліктності в екіпажі.

Дослідження показують, що основними показниками організованості сумісної діяльності, як критерію надійності, є розподіл відповідальності між учасниками спільної діяльності в танковому екіпажі, статуснорольова структура групи, що припускає відповідність функціональному розкладом по бойовому розрахунку i можливу зміну формальної ієрархії та структурованості в зв'язку з нестандартними умовами діяльності, а також типовий спосіб поведінки членів групи в екстремальній ситуації. Сугтєве значення набувають такі показники як перерозподіл відповідальності, дублювання дій один одного в бойових розрахунках, підстрахування i доповнення дій [12].

Організованість сумісної діяльності передбачає також i урахування показників, пов'язаних 3 управлінськими діями між членами екіпажу, вплив авторитету лідерів групи на прийняття рішень у спільній діяльності та способи їх реалізації. Важливе місце в прояві організованості займає тип ціннісно-орієнтаційної спрямованості діяльності членів екіпажу (на себе, на екіпаж, на результат), що може бути досліджений за показником «типовий спосіб поведінки в групі» [6].

Відмітимо, що для осмислення групової надійності необхідно врахувати ті специфічні характеристики, які відображають зміст спільної діяльності танкового екіпажу ЗС України. Оскільки це специфічна військовоорганізаційна підсистема підрозділу 3 


\section{Питання психології}

притаманними їй інтегративними якостями, що визначає іï дієздатність та відображається в постійній високій бойовій готовності, якісному вирішенні бойових, навчальних, службових та ін. завдань. Така підсистема володіс чіткою структурною ієрархією, яка визначається військовими статутами та відповідними нормативними документами. Характер взаємин між танкістами в екіпажі багато в чому визначається матеріально-технічними особливостями машин, відповідно до чого складаються умови життєзабезпечення i бойової діяльності екіпажу. Жорстко регламентований алгоритм спільної бойової діяльності танкового екіпажу сприяє тому, що між військовослужбовцями різних категорій складаються різноманітні і специфічні відносини. Вони визначаються також груповим характером обслуговування i використання зброї та бойової техніки, експлуатаційного обладнання, позначених відповідно до нього колом посадових обов'язків. Виконання функціональних обов'язків екіпажем танку носить виключно взаємозалежний характер. Танкісти орієнтовані виключно на співпрацю і взаємодопомогу, без чого неможливе якісне виконання завдань в умовах обмеженого простору і повної залежності життя кожного члена екіпажу від успіху розв'язуваних колективних завдань. Це сприяє створенню особливого, властивого тільки цій групі людей соціально-психологічного клімату, утворення специфічних групових традицій, досвіду, стереотипів, цінностей тощо.

Отже, проведений аналіз існуючих теоретичних та емпіричних досліджень психологічних особливостей надійності особистості в межах сумісної діяльності в групі дав змогу визначити наступну модель психологічної надійності танкового екіпажу (рис. 1.)

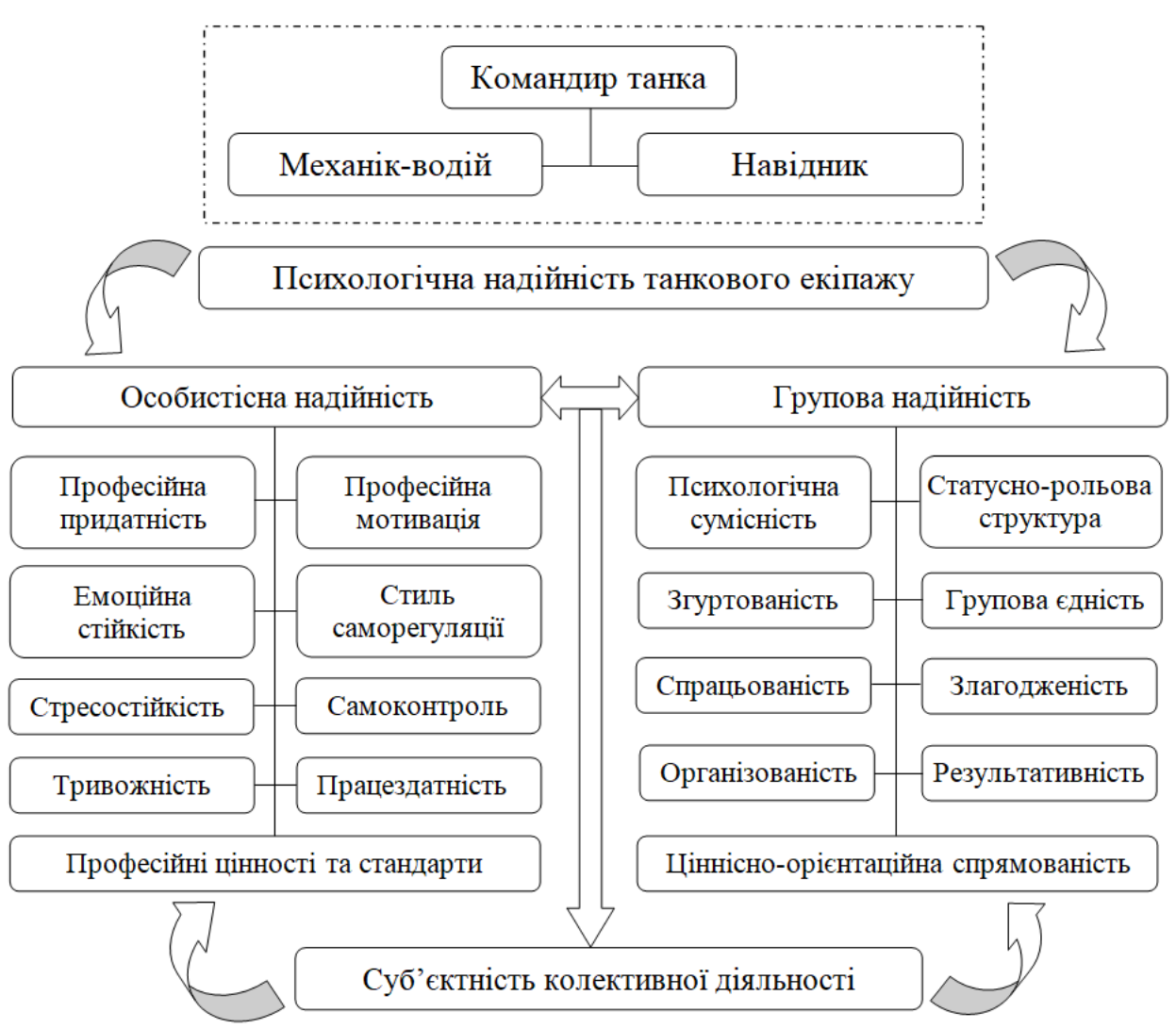

Рис. 1. Модель психологічної надійності танкового екіпажу

Нами було виокремлено такі змістові професійна мотивація, емоційна стійкість, компоненти психологічної надійності стиль саморегуляції, стресостійкість, танкового екіпажу як: складові особистісної самоконтроль, тривожність, працездатність, надійності (професійна придатність, професійні цінності та стандарти) та складові 


\section{Питання психології}

групової надійності (результативність сумісної діяльності танкового екіпажу, психологічна сумісність, статусно-рольова структура групи, згуртованість, групова єдність, спрацьованість, злагодженість, організованість, ціннісноорієнтаційна спрямованість). Разом 3 тим важливим компонентом психологічної надійності танкового екіпажу виступає суб'єктність колективної діяльності, що відображає зміст спрямованості й рівень групової активності, грунтується на груповій ідентичності, позитивному взасмному ставленні в досвіді професійних взаємовідносин визначаючи тенденцію i здатність до ініціації та регулювання групової професійної активності відповідно до групових критеріїв ефективності і доцільності в ситуаціях, що передбачають певну свободу вибору й відповідальність за нього.

Висновки та перспективи подалыших досліджень. Таким чином на основі проведеного аналізу специфіки особистісної надійності професіонала у групі та надійності групи розроблено модель психологічної надійності танкового екіпажу, в якій відображено ії змістові компоненти як цілісної групи у складі особистісної надійності (професійна придатність, професійна мотивація, емоційна стійкість, стиль саморегуляції, стресостійкість, самоконтроль, тривожність, працездатність, професійні цінності та стандарти) та групової надійності (результативність сумісної діяльності танкового екіпажу, психологічна сумісність, статусно-рольова структура групи, згуртованість, групова єдність, спрацьованість, злагодженість, організованість, ціннісноорієнтаційна спрямованість), поєднаних суб'єктністю колективної діяльності, що відображає зміст спрямованості й рівень групової активності, грунтується на груповій ідентичності, позитивному взаємному ставленні в досвіді професійних взаємовідносин визначаючи тенденцію i здатність до ініціації та регулювання групової професійної активності.

Перспектива подалыших досліджень полягає у виявленні емпіричних індикаторів визначених компонентів особистісної надійності професіонала у групі та психологічної надійності танкового екіпажу в динаміці розвитку за екстремальних умов військово-професійної діяльності.

\section{Список використаних джерел}

1. Бодров В.А. Психология профессиональной пригодности. М.: ПЕР СЭ, 2001.512 с.

2. Горбунова В. В. Психологія командотворення: ціннісно-рольова парадигма. Дисертація д-ра психол. наук: 19.00.05. Ін-т соц. і політ. психології НАПН України. Київ, 2014. 280 с.

3. Горностай П. П. Групова ідентичність у малих групах освітнього середовища. Наукові студї із соціальноїта політичної психології. 2014. Вип. 34. С. 127-138.

4. Дебренюк А. П. Психологічна сумісність військових операторів радіолокаційних станцій під час виконання службових завдань в особливих умовах [Текст] : автореф. дис. ... канд. психол. наук : 19.00.09; Нац. ун-т оборони України ім. Івана Черняховського. Київ, 2018. 19 с.

5. Корнещук В.В. Теорія і практика формування професійної надійності майбутніх спеціалістів соціономічної сфери діяльності : автореф. дис. ... д-ра пед. наук: 13.00.04; Південноукр. нац. пед. ун-т ім. К.Д.Ушинського. О., 2010.44 с.

6. Котик І.О., Саричев С.В. Надійність групи та особистісна надійність у групі. Проблеми сучасної психології. Збірник наукових прачь К-ПНУ імені Івана Огієнка, Інституту психологї імені Г.С.Костюка НАПН Украӥни. 2016. Вип. 32. С. 245-265.

7. Котик І.О., Саричев С.В. Експериментальне дослідження надійності особистості й групи в напружених і екстремальних умовах життєдіяльності. Проблеми сучасної психології. Збірник наукових праџь Кам'янещь-Подільського наџіонального університету імені Івана Огієнка, Інституту психології імені Г.С. Костюка НАПН Украӥни. Вип. 33. 2016. С. 291-313.

8. Кризова психологія: навчальний посібник / За заг. ред. проф. О.В. Тімченка. Х.: НУЦЗУ, 2010. 401 с.

9. Крук В. М. Психология надёжности специалиста: история и современность. Вестник Московского государственного областного университета. Серия: Психологические науки. 2010. № 3. С. 181-188. 


\section{Питання психології}

10. Лєбєдєва С. Ю., Тімченко О. В. Психологічне забезпечення професійної та функціональної надійності фахівців снайперських груп спеціальних підрозділів МВС України : монографія. Харків : Видво ХНАДУ, 2005. 326 с.

11. Осьодло В. І. Психологія професійного становлення офіщера : монографія. К.: ПП «Золоті ворота», 2012. $463 \mathrm{c}$.

12. Сарычев С.В., Чернышев А. С. Социально-психологические аспекты надежности группы в напряженных ситуациях совместной деятельности. Курск : Изд-во КГПУ, 2000. 180 с.

13. Сетров М. И. Основы функциональной теории организации. Л.: Наука, 1972. 163 с.

14. Шпак Р.А. Психофізіологічне забезпечення надійності професійної діяльності військових радіотелеграфістів : автореф. дис... канд. психол. наук: 19.00.02; Ін-т психології ім. Г.С.Костюка АПН України. К., 2004. 20 с.

\section{References}

1. Bodrov, V. A. (2001) Psihologiya professionalnoy prigodnosti [Psychology of professional suitability]. M $\therefore$ PER SE. 512 (in Russian).

2. Gorbunova, V. V. (2014) Psychology of team building: value-role paradigm [PsihologIya komandotvorennya: tsInnIsno-rolova paradigma]. DisertatsIya d-ra psihol. nauk: 19.00.05. In-t sots. I polit. psihologiyi NAPN Ukrayini. Kiyiv. 280 (in Ukrainian).

3. Gornostay, P. P. (2014) Grupova identichnist u malih grupah osvitnogo seredovischa [Group identity in small groups of the educational environment]. Naukovi studiyi iz sotsialnoyi ta politichnoyi psihologiyi. Vip. 34 . 127-138 (in Ukrainian).

4. Debrenyuk, A. P. (2018) Psihologichna sumisnist viyskovih operatoriv radiolokatsiynih stantsiy pid chas vikonannya sluzhbovih zavdan $\mathrm{v}$ osoblivih umovah [Psychological compatibility of military radar operators during the performance of official duties in special conditions] : avtoref. dis. ... kand. psihol. nauk : 19.00.09; Nats. un-t oboroni Ukrayini Im. Ivana Chernyahovskogo. Kiyiv. 19 (in Ukrainian).

5. Korneschuk, V. V. (2010) Teoriya i praktika formuvannya profesiynoyi nadiynosti maybutnih spetsialistiv sotsionomichnoyi sferi diyalnosti [Theory and practice of formation of professional reliability of future specialists of the socionomic sphere of activity]: avtoref. dis. ... d-ra ped. nauk: 13.00.04; Pivdennoukr. nats. ped. un-t Im. K.D.Ushinskogo. O. 44 (in Ukrainian).

6. Kotik, I. O., Sarichev, S. V. (2016) Nadiynist grupi ta osobistisna nadiynist u grupi [Group reliability and personal reliability in the group]. Problemi suchasnoyi psihologiyi. Zbirnik naukovih prats K-PNU ImenI Ivana Ogienka, Institutu psihologiyi imeni G.S.Kostyuka NAPN Ukrayini. V. 32. 245-265 (in Ukrainian).

7. Kotik, I. O., Sarichev, S. V. (2016) Eksperimentalne doslidzhennya nadiynosti osobistosti y grupi v napruzhenih i ekstremalnih umovah zhittediyalnosti [Experimental study of the reliability of the individual and the group in stressful and extreme living conditions]. Problemi suchasnoyi psihologiyi. Zbirnik naukovih prats K-PNU ImenI Ivana Ogienka, Institutu psihologiyi imeni G.S.Kostyuka NAPN Ukrayini. V. 33. 291-313 (in Ukrainian).

8. Krizova psihologiya: navchalniy posibnik [Crisis psychology: a textbook]. Za zag. red. prof. O.V. Timchenka. H.: NUTSZU, 2010. 401 (in Ukrainian).

9. Kruk, V. M. (2010) Psihologiya nadyozhnosti spetsialista: istoriya i sovremennost [Psychology of specialist reliability: history and modernity]. Vestnik Moskovskogo gosudarstvennogo oblastnogo universiteta. Seriya: Psihologicheskie nauki.\# 3. 181-188 (in Russian).

10. Lebedeva, C. Yu., Timchenko, O. V. (2005) Psihologichne zabezpechennya profesiynoyi ta funktsionalnoyi nadiynosti fahivtsiv snayperskih grup spetsialnih pidrozdiliv MVS Ukrayini [Psychological support of professional and functional reliability of specialists of sniper groups of special units of the Ministry of Internal Affairs of Ukraine] : monografiya. Harkiv : Vid-vo HNADU. 326 (in Ukrainian).

11. Osodlo, V. I. (2012) Psihologiya profesiynogo stanovlennya ofitsera [Psychology of professional becoming an officer]: monografiya. K. : PP «Zoloti vorota». 463 (in Ukrainian).

12. Saryichev, S. V., Chernyishev, A. S. (2000) Sotsialno-psihologicheskie aspektyi nadezhnosti gruppyi v napryazhennyih situatsiyah sovmestnoy deyatelnosti [Socio-psychological aspects of group reliability in stressful situations of joint activity]. Kursk : Izd-vo KGPU. 180 (in Russian).

13. Setrov, M. I. (1972) Osnovyi funktsionalnoy teorii organizatsii [Fundamentals of functional organization theory]. L.: Nauka. 163 (in Russian).

14. Shpak, R. A. (2004) Psihofiziologichne zabezpechennya nadiynosti profesiynoyi diyalnosti viyskovih radiotelegrafistiv [Psychophysiological support of professional reliability of military radiotelegraphists] : avtoref. dis... kand. psihol. nauk: 19.00.02; In-t psihologiyi Im. G.S.Kostyuka APN Ukrayini. K. 20 (in Ukrainian). 


\title{
Питання психології
}

\author{
Резюме \\ Кучерява Т. соискатель научно-исследовательской лаборатории \\ экстремальной и кризисной психологии научно-исследовательского \\ центра Наџионального университета гражданской защчтть Украинь \\ МОДЕЛЬ ПСИХОЛОГИЧЕСКОЙ НАДЕЖНОСТИ ТАНКОВОГО ЭКИПАЖА
}

Статья посвящена проблеме психологической надежности группь при выполнении коллективной деятельности. Проанализировань особенности исследования надежности личности в индивидуальной деятельности специалиста с позиции инженерной психологии, индивидуально-психологические характеристики профессиональной надежности субъекта деятельности и надежности профессиональной деятельности специалистов экстремального профиля. Определена специфика личностной надежности профессионала в группе и надежности группь. Разработана модель психологической надежности танкового экипажа, в которой отражены содержательные компоненть психологической надежности танкового экипажа как изелостной группь в составе личностной надежности и групповой надежности, объединенных субъектностью коллективной деятельности.

Ключевые слова: танковый экипаж; психологическая надежность; групповая деятельность; личностная надежность; групповая надежность; модель психологической надежности.

\section{Summary \\ Kucheryava T. candidate of the research laboratory of extreme and crisis psychology of the research center of the National University of Civil Defense of Ukraine}

MODEL OF PSYCHOLOGICAL RELIABILITY OF A TANK CREW

Introduction. The article is devoted to the problem of psychological reliability of the group during the performance of collective activities. The specifics of personal reliability of a professional in a group and reliability of a group are determined. A model of psychological reliability of the tank crew has been developed.

Purpose. Determination of psychological features of personality reliability in group activity and development of model of psychological reliability of tank crew.

Methods. A set of theoretical methods was used to solve the problem formulated in the article: analysis, comparison, generalization, systematization of the obtained information, interpretation of data.

Originality. For the first time a model of psychological reliability of a tank crew was developed. The practical significance of the obtained results of the research lies in the use of the obtained data in the system of psychological support of servicemen of the land forces of the Armed Forces of Ukraine during the performance of assigned tasks.

Conclusion. The analysis of the existing theoretical and empirical researches of psychological features of reliability of the person within the limits of joint activity in group allowed to define the following model of psychological reliability of the tank crew. We have identified such semantic components of psychological reliability of the tank crew as: components of personal reliability (professional suitability, professional motivation, emotional stability, style of self-regulation, stress resistance, self-control, anxiety, performance, professional values and standards) and components of group reliability (effectiveness of joint activities of the tank crew, psychological compatibility, status-role structure of the group, cohesion, group unity, efficiency, coherence, organization, value-oriented orientation). However, an important component of the psychological reliability of the tank crew is the subjectivity of collective activity, which reflects the content of the focus and level of group activity, based on group identity, positive relationship in the experience of professional relationships determining the tendency and ability to initiate and regulate group criteria of efficiency and expediency in situations that provide a certain freedom of choice and responsibility for it.

The prospect of further research is to identify empirical indicators of certain components of the personal reliability of the professional in the group and the psychological reliability of the tank crew in the dynamics of development under extreme conditions of military-professional activity.

Key words: tank crew; psychological reliability; group activities; personal reliability; group reliability; model of psychological reliability.

Recelved/Поступила: 21.12. 20. 